\title{
Webpage Design and Quality of Seaside Tourism Destinations: A Question of Collaboration
}

\author{
Jens Blumrodt $^{1} \&$ Adrian Palmer $^{1}$ \\ ${ }^{1}$ ESC Rennes School of Business, France \\ Correspondence: Jens Blumrodt, ESC Rennes School of Business, Department Management and Organization, 2 \\ rue Robert d'Arbrissel, CS76522, 35065 Rennes, France. E-mail: jens.blumrodt@esc-rennes.fr
}

Received: September 17, $2012 \quad$ Accepted: October 11, $2012 \quad$ Online Published: August 20, 2013

doi:10.5539/ibr.v6n9p1 URL: http://dx.doi.org/10.5539/ibr.v6n9p1

\begin{abstract}
The Internet has become increasingly important for promoting tourism destinations. Place branding has become an important marketing tool as destinations use it strategically and tactically to promote their unique advantages. However, at both a strategic and tactical level, place brands have to satisfy the needs of a wide range of stakeholders, often involving long and time consuming channels of negotiation before a strategy is agreed. A consequence is a frequent disjuncture between a place brand 'as officials wish that it is' and 'as it actually is'. This exploratory research analyses different tourism office websites from French and English seaside tourism destinations. Our approach combines two different methods. First, we present the specific communicated images. Second, interviews with officials of these cities compare the communicated image to the desired one. Tourism seaside destination brand image is made up of specific brand image factors. We find that cities with a similar environment communicate elements of their natural settings as well as other brand elements but the communicated image does often not fit with the desired brand image. It is evident that the characteristics of collaboration between different entities impacts on the quality of designed websites.
\end{abstract}

Keywords: city branding, e-marketing, brand image, tourism marketing, communication, destination marketing

\section{Introduction}

Highlighting the most valuable assets of a city is not a new concept. In the 19th century, competition was growing between places. The globalization of markets forces tourist destinations to adopt a distinctive positioning (Gold \& Ward, 1994; Ward, 1998). Unlike other product brands, which are driven predominantly by customers' needs, city branding and place marketing are typically driven by the often conflicting needs of diversifying local economies faced with industrial decline, attracting inward investment and attracting tourism (Kotler et al., 1993; Matson, 1994). Anholt (2006; 2010) shows that branding of places and cities has gained popularity and cities use specific events to enhance their image, as the Olympics of Beijing have shown (Mobley, 2008). Cities that change their image to a more specific, coherent, and clearly defined brand gain visibility and reputation, as the example of "Das Neue Berlin" (The new Berlin) makes evident (Ashworth \& Kavaratzis, 2007). Internet based technologies have played a crucial role as a facilitator of access to information and of tourists' reservations (McLemore \& Mitchell, 2001).

A review of existing destination management websites reveals a number of approaches to evaluation research (Han \& Mills, 2006). Content analysis is the most common approach. Scorecard approaches are common, facilitated by a vast accessible amount of quantitative information just with a click of a mouse (destination weather conditions, currency rates, ticket prices, and flight tracking) and qualitative information (cultural events, political conditions, and visual imagery) (Rayman-Bacchus \& Molina, 2001). An analysis of cities' websites shows a variety of different city images. Those differences of city brand images might be explained with the number of habitants, tourists or both (Woodside, Vicente, \& Duque, 2011). It seams evident that bigger cities have a greater number of brand elements to communicate. The underlying concept is that city's brand image is likely to reveal the extent of the complexity of a city brand (Parkerson \& Saunders, 2004). A rich brand image might nevertheless not mean that the image fits with officials' desired image nor that the delivered image is of good quality. The perceived quality and differences in websites brand image delivered for those cities is not solely based on technical issues (Blumrodt \& Palmer 2012; Grant, 2007). The promotion of places (city, region or nation) as tourism destinations involves collaboration between multiple parties, typically, elected members of 
government bodies, officers of those bodies and external agencies who provide web design and management services.

Although previous studies have analysed the development of destination images in an offline context, little research has been undertaken to understand how destination images are formed and sustained in an online environment. The contribution of this study is therefore to understand the processes by which destination brands are created online and whether they accurately reflect the interests of key stakeholders.

\section{Background}

\subsection{Destination Branding and Branding Concepts}

The topic of tourism destination branding has been the subject of considerable discussion (Anholt, 2010; Kearns \& Philo, 1993). While the need for place/destination branding is widely recognised there is nevertheless confusion about its nature and scope. There is very little common theory to reflect "what" we are doing; research and other contributions have focused on the way of branding, in other words, the "how" has been the focus for discussion (Hanna \& Rowley, 2008; Lucarelli \& Berg, 2011). This is also linked to the fact that brand image perceptions contrast strongly due to the variety of target groups (Zenker, 2009). City brand rankings (cf. Anholt-GMI City Brands Index (in Anholt, 2006) or the Saffron European City Brand Barometer (cf. Hildreth, 2010)) demonstrate the importance given to city branding. Place branding becomes more popular and marketing strategies are shifting to strategic place/destination brand management (Kavaratzis, 2009). Tsiotsou and Ratten highlight that there are still areas that need to be addressed in order to have a more global and refined understanding of where tourism research is heading: "One of the most important concepts linked to branding is brand equity" (Tsiotsou \& Ratten, 2010, p. 536).

A destination brand image has to be credible in the eyes of target visitors and linked to brand reality. Brand image comprises cognitive and affective dimensions. The brand should influence destination choice and branding concepts are largely based on destination image (Morgan \& Pritchard, 1999). Destination image can be defined as not only based on the perceptions of individual destination attributes but also the holistic impression made by the destination (Echtner \& Ritchie, 1991). Tourism destinations promote themselves through destination-wide websites, but there is a problem of knowing what image to promote. "If a city official decides to initiate a place branding strategy, how will they know what and whom to be looking for if not even scholars can decide what it is about?" (Kalandides, 2011: 282-283).

Our study focuses on websites' communicated image. Seaside destinations promote similar attributes such as the beauties of the location, history, and heritage. Those brand associations can be classified in three major categories, attributes, benefits and attitudes (Keller 1993; 2008). Attributes are descriptive features linked to the product: they can be product-related or non-product related. Non-product related attributes are the external aspects of the product or service that relate to its purchase or consumption. Customers' benefits are a personal value the consumer attaches to the product attributes - that is, what consumers think the product or service can do for them. Brand attitudes are the overall evaluation of a brand. We assume that these are the three categories which are communicated through tourism office websites.

\subsection{Destination Image as a Collaborative Product}

Image projection involves a process of communication a message from the sender - in our case the destination marketing organisation - to the receiver - the internet user and potential tourist (Thill \& Bovee, 2010). The sent message is encoded by the webmaster, acting on behalf of the stakeholders in the tourism destination marketing organisation. The planning of promotional campaigns is no longer typified by simplistic, one-dimensional relationships. Collaboration between a range of stakeholders is a condition for successful marketing communication campaigns (Grimes, 2004); there is a shift from collaboration beyond the preserve of advertising agencies to a range of networks (Kim, Han, \& Schultz, 2004). In other words there is a growing demand for connectedness and integration driven by clients whose businesses have become increasingly based on collaboration and interaction. Clients look rather for "strategic partners to help them establish a clearly differentiated position and brand personality across all media channels" (Grant, 2007: 427). In this case, quality of tourism destination websites may reflect the quality of collaboration between the principal stakeholders. Deficiencies in this interaction between the key stakeholders - typically city council, tourism office, private sector tourism operators and webmaster - may be a source of a destination's website giving it a competitive disadvantage (see Figure 1). 


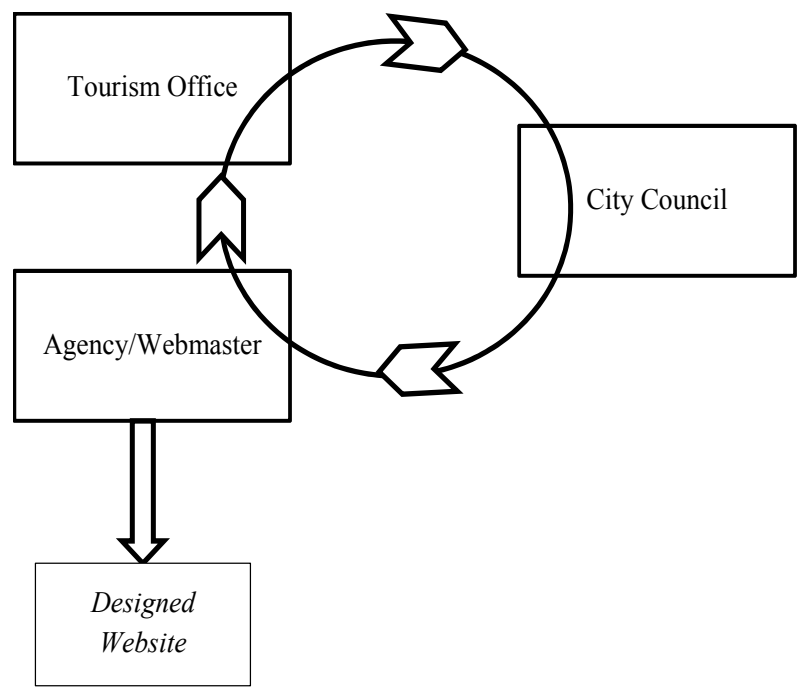

Figure 1. Interaction between different actors involved in website creation

As for the interaction between top management and line managers (Savaneviciene \& Stankeciciute, 2011) a lack of interaction between the different actors responsible for city branding can make the organization fail to achieve goals. The success of the organization depends widely on how effectively the internal activities are managed and how well its behaviour fits with the environmental conditions. The destination website which faces the public is not only the result of webmaster competence but also the outcome of collaboration quality. Our study seeks to explain the consistency between tourism goals of a city, websites' brand associations, and the quality of the designed image. We formulate the following research questions:

1) Are the publicly expressed tourism goals of a town consistent with the brand associations presented on its website?

2) What factors distinguish tourism destinations with high consistency between publicly expressed goals and website content and those where there is inconsistency?

We assume that three brand categories are communicated through tourism office websites. We complete Caldwell and Freire's (2004) destination branding model, based on functional and symbolic dimensions. Compared to previous research we "catch" the communicated image and compare these elements to the desired image expressed by officers and elected members responsible for developing tourism policy in the town.

\section{Methods}

Our study focuses on French and English seaside destination brands. France has a rich history and a huge diversity of tourist destinations and offers exceptional seaside tourism, evidenced by the hundreds of kilometres of coastline. Since the end of the 1990s France has been the leading international tourism destination in terms of arrivals (World Tourism Organization, 2012). English seaside tourism destinations are in a sense the direct neighbours/competitors.

\subsection{City Selection}

The choice of tourist towns and their websites was based on their proximity to the sea and the emphasis of seaside culture. We select four well known French seaside tourism destinations. The cities are located at the Atlantic seaside in the southwest of France. These places are situated in different regions on the French sea side. As a comparison, we chose four English seaside towns.

We assessed the websites of the selected towns on 12 January 2013. The eight towns have a different number of habitants (Table 1). Big towns as tourism destinations at the French West coast are lacking. In France, the coast is protected by law against over development, and this has reduced construction and urbanization in coastal areas. 
Table 1. Selected seaside destinations

\begin{tabular}{ll}
\hline City & Web Address \\
\hline French Tourism Office Websites & http://www.deauville.org/fr/ \\
Deauville & http://www.ot-dinard.com/ \\
Dinard & http://www.hossegor.fr/ \\
Hossegor & $\mathrm{http} / /$ www.saint-malo-tourisme.com/ \\
Saint Malo & \\
English Tourism Office Websites & \\
Bournemouth & $\mathrm{http} / /$ www.visitbournemouth.com/ \\
Plymouth & $\mathrm{http} / /$ www.visitplymouth.co.uk/ \\
Poole & $\mathrm{http} / /$ www.pooletourism.com/ \\
Sidmouth & $\mathrm{http} / /$ www.visitsidmouth.co.uk/ \\
\hline
\end{tabular}

\subsection{Exploration Semantic Issues}

Florek, Insch and Gnoth (2006) investigated the place branding of New Zealand's city council websites. The authors developed a conceptual framework to identify the elements of place brand on websites. The result was the identification of a tool that measures place brand on city council websites. Regarding their framework the authors do not integrate existing theories and recognized brand image elements. Parkerson and Saunders (2004) developed a grouping of the elements and categories derived from a consumer's perception about a place. To reveal the underlying dimensions, a division between tangible and intangible parts has proved useful. For this research we use the primary web pages defined as those primarily referring to:

1. Home page/Welcome page

2. Site map

3. Access

4. General/Practical Information

5. History/Culture

6. What to do/Activities

7. Where to stay/Accommodation

8. Where to go out/Eating or Drinking

9. Events/Events Calendar

10. Social Network (Facebook, Twitter, Linkedin)

These pages are converted into PDF files and then analyzed. The analysis tool has been generated by exploratory interviews with stakeholders and literature. The defined pages of the websites are analyzed by categorizing the semantic content. The destination brand image appears with the different categories (1. Product related attributes $\&$ non-product related attributes, 2. Benefits, and 3. Attitude.) which are specified by factors, and items. It is expected, that the emitted brand image will vary depending on the analyzed website. Together, they will generate the cities' brand image.

We measure the occurrence and frequency of different words; they are enumerated, checked and counted. The original tool (WEFTQDA) for measuring place brand elements on city tourism websites (Blumrodt, 2011) explores the use of the software. It is our intention to continue the exploration of this tool and to examine whether or not the identification of place brand elements using French Sphinx Lexica ${ }^{\circledR}$ positively correlates to 
the findings of the exploratory analysis (cf. http://www.sphinxsurvey.com/).

\subsection{Exploratory Analysis}

In order to collect qualitative data regarding the expectations of city officials, the Mayor's offices of tourist cities were contacted, interviews set up by phone or in-person. They were guided by a semi-structured questionnaire. Similar questions are asked to the different elected officials responsible for tourism. The discussion guidelines covered the following issues:

How important is tourism to the life of your city?

Do you have a predetermined strategy for the city's image?

If so, how was it created? How is it communicated?

What would you say are the main elements of your city as a brand?

How do you determine these qualities?

Is the brand image important for your city as a tourism destination?

What are your expectations for the website of the city's office of tourism?

Who is managing the website? How many people take care of the office of tourism website?

Do you currently employ website analytics to your website?

Do they meet your expectations?

We measured the intended brand elements. This generates a comparative analysis between the real/communicated (office of tourism website) brand elements which have been put in place by the politicians via the tourism office and webmasters (city officials' expectations). Interviews with the officials made known more precisely what is expected by these persons. These interviews have been conducted by English or French native speakers. To be as accurate as possible, we recorded and transcribed these interviews. Analysis of the interviews has been undertaken (nVivo).

\section{Results}

The product related attributes of seaside tourism destinations are related to three main factors, the natural and architectural heritage, as well as the existing facilities. In Figure 2, the natural heritage is reflected by four (nature, beach, country and sea), the architectural by three (architecture, museum churches), and the facilities by eleven items (leisure, activities, sport, golf, tennis, windsurfing/surfing, camping, hotel, restaurant, shopping, boat).

Three brand benefits factors determine tourists' brand experience. Family linked aspects, discovery, and social network (facebook, linkedin, twitter youtube, blog). The brand attitudes factors are based on substantives and adjectives which do not figure on the websites (city size and international), others cannot be recognized as an item but are linked to writing style skills (narrative). If the 1st and 2nd FA have been generated during the next step of analysis, the 3rd FA is linked to researchers' overall assessment of the writing style. The last FA of this category is linked to sustainable development, therefore items have been recognized ("green" and, or "preserved, social, responsible development").

In this first presentation, city-brand associations on websites have been identified for seaside tourism destinations. The next step counts items. Results of our counting method are regrouped to Factors (Table 2: FA).

Below the observed categories, the sum of all observed items is indicated, their means, and the means of items while the product related attributes are excluded.

We notice for all tourism destinations a large score of natural heritage and facilities items. Natural aspects and attractiveness of city Tourism destinations are in the heart of brand image. This is observed from the initial approach. Content and semantic issues: The content is focussing on natural aspects and physical attractiveness. Product related attributes are (over-) represented compared to other factors of the brand image. We confirm that different kinds of brand associations exist and they can be categorized for all tourism destinations.

If we take other means as basis of observation (other means excluding product related attributes), several tourism destinations focus also on other factors. Different elements appear specifying their point of view concerning the city's brand image and the importance accorded to online communication. The tourism destinations are focussing on other aspects then only the city's and region's beauty. 


\section{Product related attributes}

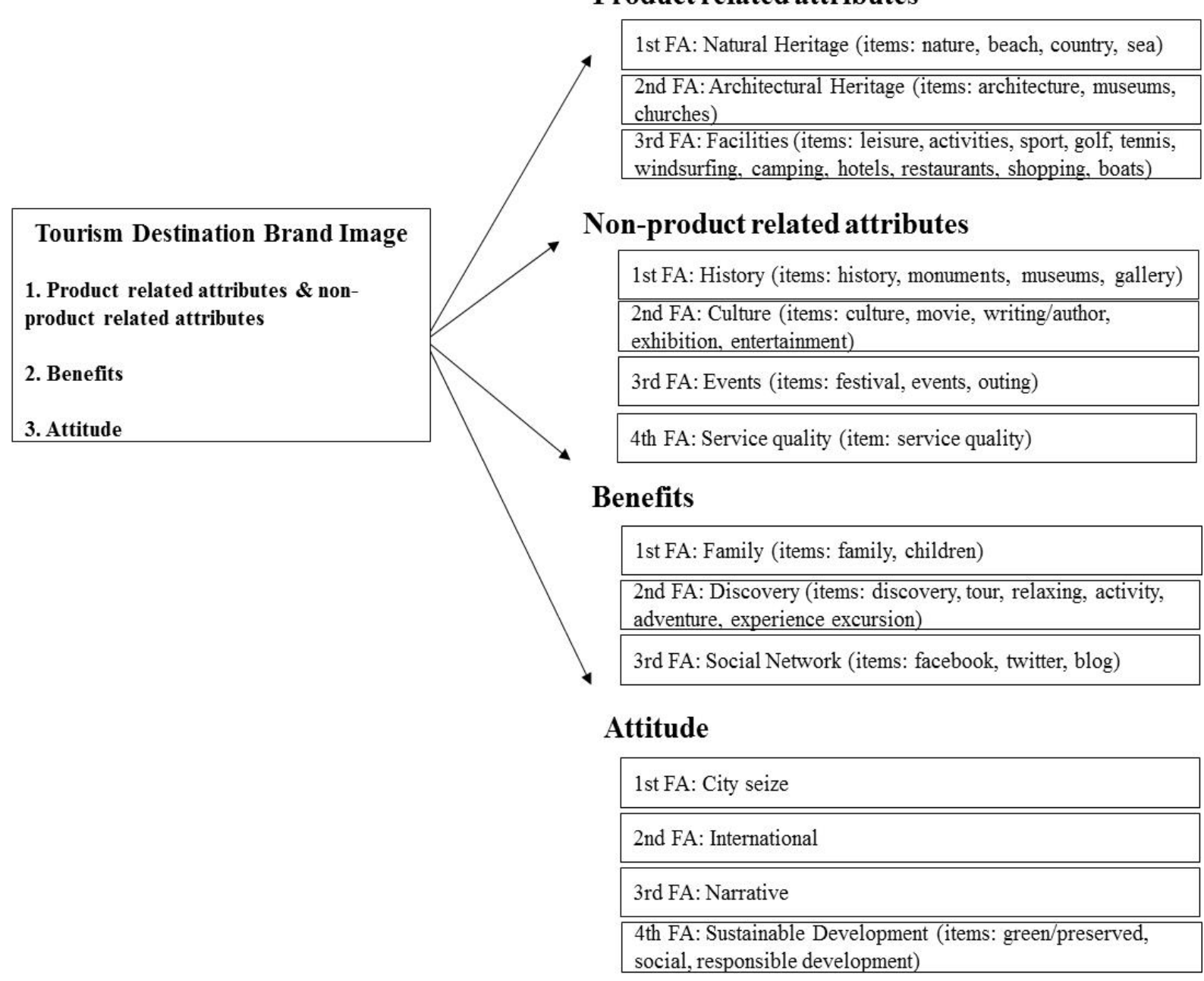

Figure 2. Concept of tourism destination brand image

Table 2. Frequency of items in tourism destination image

\begin{tabular}{ccccccccc}
\hline FA and items & Deauville & Dinard & Hossegor & Saint Malo & Bournemouth & Plymouth & Poole & Sidmouth \\
\hline Natural Heritage & 51 & 6 & 11 & 46 & 6 & 10 & 25 & 10 \\
Architecture Heritage & 2 & 0 & 0 & 6 & 1 & 2 & 9 & 11 \\
Facilities & 56 & 8 & 27 & 55 & 12 & 19 & 54 & 28 \\
History & 4 & 0 & 0 & 8 & 6 & 5 & 11 & 5 \\
Culture & 25 & 1 & 1 & 28 & 4 & 10 & 6 & 6 \\
Events & 14 & 0 & 2 & 9 & 3 & 8 & 16 & 7 \\
Quality & 8 & 0 & 2 & 0 & 1 & 1 & 1 & 2 \\
Family & 3 & 3 & 2 & 6 & 4 & 4 & 16 & 3 \\
Discovery & 11 & 5 & 4 & 18 & 4 & 5 & 36 & 9 \\
Social Netw. & 1 & 2 & 0 & 4 & 1 & 0 & 0 & 0 \\
Sustainable & 7 & 0 & 1 & 3 & 0 & 0 & 5 & 2 \\
Total of items/sum & 182 & 25 & 50 & 183 & 42 & 64 & 179 & 83 \\
Mean & 17 & 2 & 5 & 17 & 4 & 6 & 16 & 8
\end{tabular}


Table 3. Officials perceptions of tourism destination brand image

\begin{tabular}{|c|c|c|c|c|c|c|c|c|}
\hline Officials & Deauville & Dinard & Hossegor & Saint Malo & Bournemouth & Plymouth & Poole & Sidmouth \\
\hline Natural & & & & Maritime & & & Famous & \\
\hline \multirow[t]{2}{*}{ Heritage } & & & & \& biotechnology & & & beaches & \\
\hline & & & & Fit & & & Fit & \\
\hline Architectural & & & & Historical & & & & \\
\hline \multirow[t]{2}{*}{ Heritage } & & & & heritage & & & & \\
\hline & & & & Fit & & & & \\
\hline \multirow[t]{5}{*}{ Facilities } & Summer and & Sport activities (for & Surf clientele & Sports & Best facilities \& & Best facilities & Water & Best facilities \\
\hline & high seasons & young & (surf sport) & Fit & water sport & $\&$ water sport & sport & $\&$ water sport \\
\hline & activities & people-associations & Fit & & activities \& other & activities & activities, & activities \\
\hline & Fit & /clubs) & & & sports & Fit & sailing, & Fit \\
\hline & & No Fit & & & Fit & & angling & \\
\hline
\end{tabular}

History

Culture

Cultural event
policy
Fit

Fit Basque culture

Literature, writer

Fit

No Fit

Family

School

holidays \&

weekends

Fit

Discover

Event driven policy Sport events

No Fit

No Fit

Event driven

policy

Fit

Quality of life

Fit

Discover about

$$
\text { Corsaire }
$$

Fit

Seize $<5$

$=10$

$<5$

thousands of

habitants

International

I 8

2

I 3

I 1

Sustainable

Development

$$
\text { Fit }
$$

$$
3 / 3
$$$$
\text { 0/2 }
$$

$2 / 2$

$1 / 3$

$2 / 3$

$7 / 7$

0/7

1/1

0/1

$\mathbf{0} / 3$

\section{Activities \\ others then \\ seaside: \\ cultural}

infrastructures

Fit $<$ ø

$(1 / 3$

$(0 / 7+0$


The strategic brand elements have been recognized during the interviews (cf. table 3); they are mentioned as corresponding factors in the left column. The first line indicates cities' names.

Different elements appear specifying their point of view concerning the city's brand image and the importance accorded to online communication.

If these elements figure as items on the city's website, the officials' perceptions of tourism destination brand image "fit" with their website designed brand image (cf. Table 3: "fit" and "No fit"). There is a gap between web-policies which can be illustrated with the examples of different desired and transmitted brand images.

Deauville, Saint Malo and Poole are considered as best practice of tourism brand communication on websites (Blumrodt, 2011). Beside the beauty of the destination there are other aspects which highlight the places' assets to attract tourists. Their brand attributes are a starting point for a more diversified brand image. These cities take, compared to their counterpart, more recent issues, such as sustainable tourism, into account. Sustainability issues have not spared the tourism sector where it is no longer seen as having no significant impact on the natural, human made and socio-cultural environment in which it is situated (Garrod \& Fyall, 2000).

These differences between the desired and transmitted image can be summarised (see Figure 3). The figure contains different information. The cities are placed in the figure with the obtained mean score (X-coordinate value); the total score of items is also mentioned. The elected officials' desired image is compared to the web-image (bottom line: Fit/No Fit).

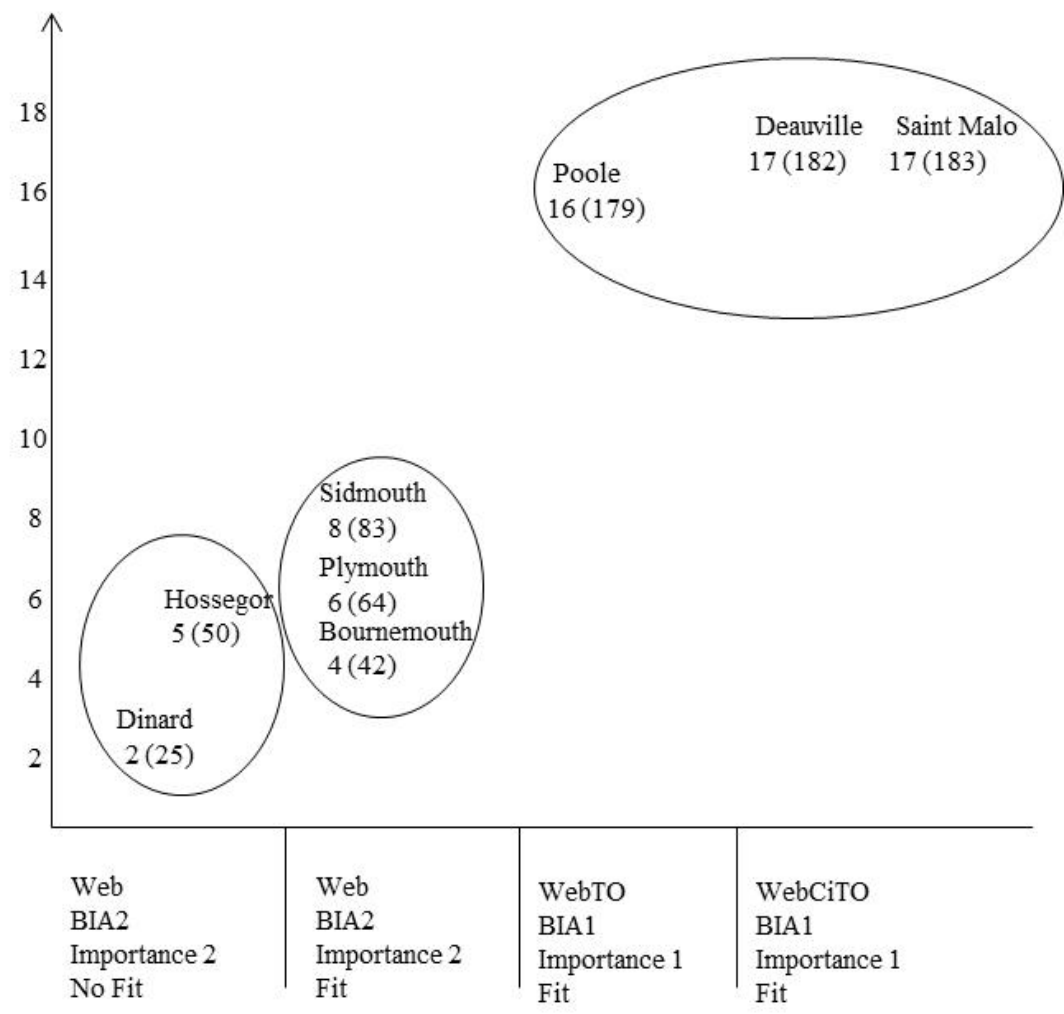

Figure 3. Brand image fit on websites and website management

Web=Delegated to Webmaster; WebTO=Webmaster and tourism office managed; WebCiTo=Webmaster, city council, and tourism office managed

The importance for tourism (Figure 3: Importance) and brand image associations (Figure 3: BIA) are assessed during the interviews with officials. The Figure mentions cities' officials who attribute a high importance to brand image or tourism (score $=1$ ). These issues are for other officials not of utmost importance (score $=2$ ). Differences are noticed concerning the websites management. Some cities have delegated the websites management to webmaster, other cities tourism offices manage with the webmaster the website, and a last group of cities manage with the tourism office and the webmaster city's webpage. 
Different categories of city websites appear. The first group (Dinard \& Hossegor) have a low score of items, especially for the mean of non-product related attributes. Their desired image does not fit with the communicated image. The officials do not attribute the highest importance to BIA and tourism. The websites management is delegated to webmasters. The second group (Bournemouth, Plymouth, \& Sidmouth) are tourism destinations with a fitting desired and transmitted image. As the first group, their brand image is not diversified. The sites are also managed by the webmaster. The third group (Poole, Deauville, \& Saint Malo) contains the best performing websites, their brand images are diversified, and the desired image fits with the transmitted image. The tourism office and the webmaster (Poole), or the city council, the tourism office, and a webmaster (Deauville \& Saint Malo) take care of the website. Image and tourism are for those officials a priority.

Brand associations do not in all cases reflect officials' tourism goals. The existent gaps between publicly expressed goals and those expressed on websites can be explained by the different management styles; these findings need further discussions.

\section{Discussion}

This study has made a contribution to our understanding of the disjuncture that frequently occurs between the brand development goals of a tourism destination marketing organisation, and the brand image that is actually communicated to target audiences. For destination marketing organisations, previous studies in an offline context have suggested that this disjuncture may be partly explained by the need to reconcile the often conflicting goals of stakeholder groups involved in the tourism destination. Our study has added further evidence of this disjuncture in an online context and noted the importance of collaborative working relationships for reducing this disjuncture.

Our study has confirmed that tourism organizations are characterized by a high degree of collaborative interaction between the public and private sectors at all levels of the destination management (Goeldner \& Ritchie, 2012). The best performing websites are managed collaboratively. Saint Malo, Deauville, and Poole have the most diversified websites where key components fit well with the desired destination brand image. The collaboration for French seaside destinations is centralized and the city council is directly linked to the tourism office (see Figure 4: link $1 \&$ I); information on the website is regularly updated with the webmaster. Meetings between the three entities are held several times a year.

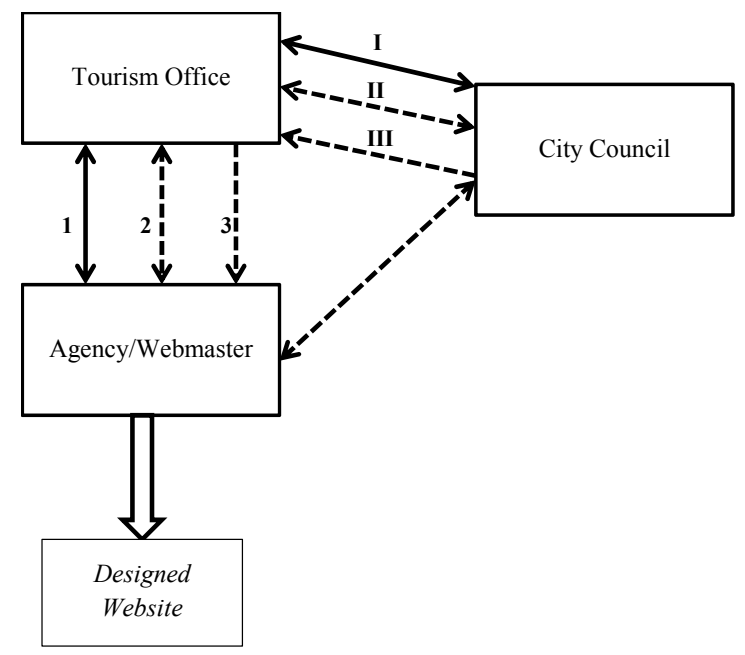

Figure 4. Confirmed model of interaction between different actors involved in website creation

The UK environment requires more independence for the tourism offices, the collaboration with the city council is informal (link II) and the collaboration with the agency direct (link 1).

Sidmouth, Plymouth, and Bournemouth websites are less diversified but the right image is communicated. Those websites can be improved while adding pertinent and significant items corresponding to the large city environment. These websites are mastered by the agency with a regular feedback from the tourism office (link 2). There is no direct link with the city council, contacts do nevertheless exist (link III).

Dinard and Hossegor have interesting websites, but they do not reflect the desired brand image. They are, as 
their English counterparts, managed by the webmaster, there is only a feedback from the tourism office (link 3 ). The city council is not involved. For these two cities the desired brand image does not fit with the city's website. This can be explained by a lacking interest of attributed "importance of tourism" and "brand image associations", the most significant argument is based on the outsourced web design to webmasters.

For many reasons officials' desired image might be distorted when it finally appears on the website. The webmaster is not the right person to design city brand images, the website's architecture and content vary greatly from one agency to another (Burford, 2011).

Collaboration operates in a 'shared power' environment in which the involved stakeholders manage different resources and knowledge and they have their own distinct bases of power and authority (Crosby \& Bryson, 2010). When the city council collaborates with the different stakeholders it assumes the role of a facilitator. This role to facilitate rather than to direct can be applied to both best practices network, the French (1\&I and link from city council to the webmaster) and the English (1\&II) collaboration style. Ansell and Gash (2012) called those facilitators "catalysts", they help to identify and realize value-creating opportunities.

Website information usefulness is not a question of high tourism destination dominance (Woodside, Vicente, \& Duque, 2011), but in general linked to the importance attributed by officials to the collaboration process. On the lowest level of website quality the website design is delegated to webmasters or on a small network between webmaster and tourism office, they appear in the bottom line (Figure 5). The corresponding cities are Dinard and Hossegor.

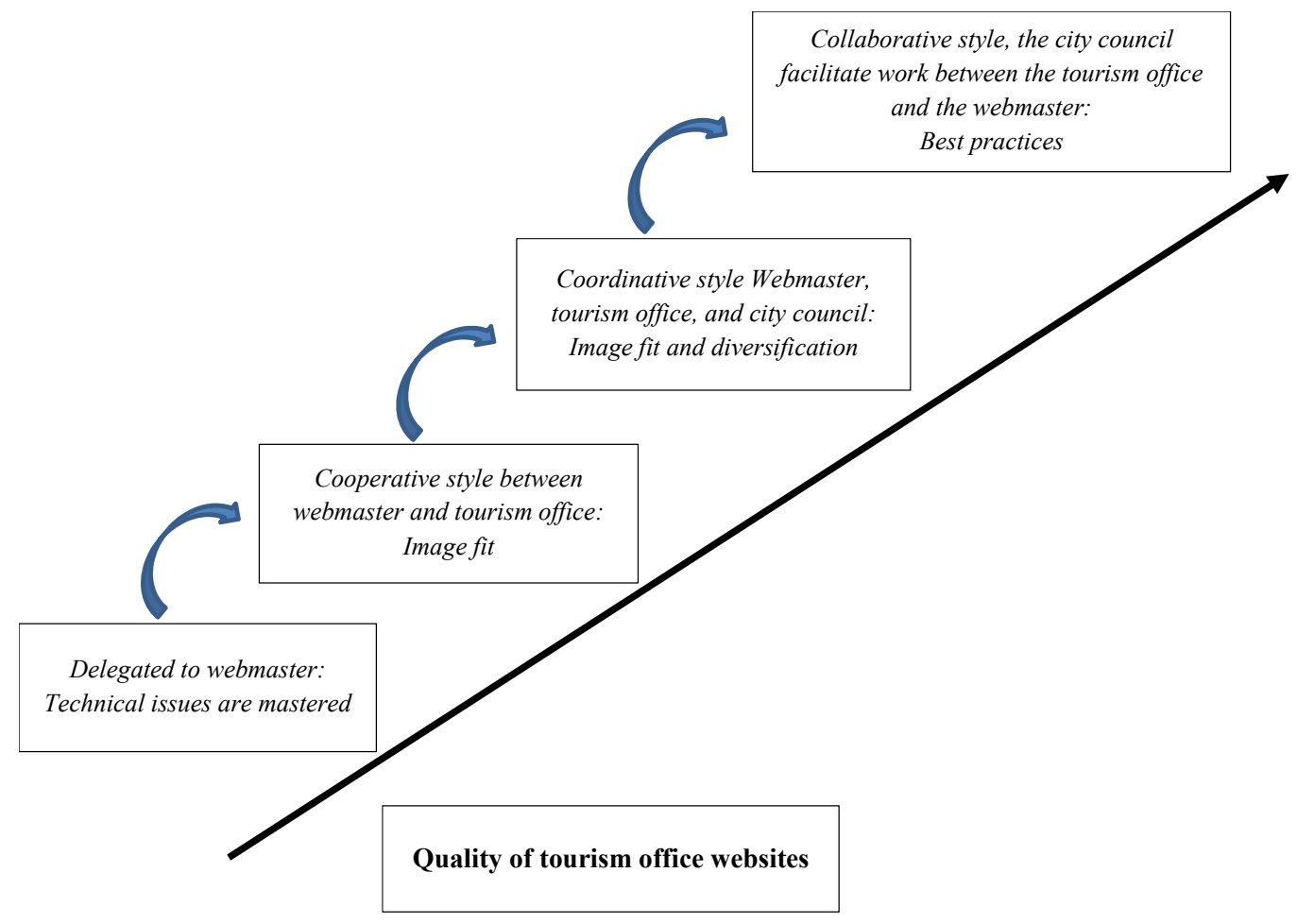

Figure 5. The impact of collaboration and centralized management style on websites

On the second, the cooperative level, contacts between the webmaster and the tourism office are established; as a consequence the simple brand image fits (Bournemouth, Plymouth, \& Sidmouth). The coordinative management style (Poole) assures a diversified website, the webmaster works regularly with the tourism office which is in contact with the city council. On the highest level (Deauville \& Saint Malo), the collaboration between the three stakeholders is engaged and the city council, as a guarantor of the city tourism policy, is fully engaged as a catalyst and facilitates the collaboration.

In terms of websites content, the traditional tourism framework of Sea-Sun-Sand and Sex of seaside tourism and the Sightseeing-Shopping-Shows-Short breaks of urban tourism are being transformed into a new tourism demand framework driven by the elements of technology, ecology/environment, education and entertainment 
and multi-culture (Buhalis, 2001), these elements do not appear as expected on websites. Also in a sustainable perspective, tourism development can be thought of as meeting the needs of present tourists and host regions while protecting and enhancing opportunity for the future leading to management of all resources in such way that can fulfil economic, social and aesthetic needs while maintaining cultural integrity, essential ecological processes, biological diversity and life support system (Inskeep, 1991).

Our results are consistent with previous research on brand associations claiming that brand association should focus on non-product related attributes for efficiently and effectively having an impact on customers (DeChernatony, 2001; De Chernatony \& Segal-Horn, 2001). Our study also revealed the correlation between collaboration and the increase of non-product related attributes. This has been one of Zenker's (2011) designed directions of future research.

The present exploratory research can be enriched in different ways. Websites are quite diverse and our research has only considered eight tourism destination websites. Our research protocol should be replicated in a geographically more diverse range of destinations. The range of items in the different categories has to be confirmed or adapted to other seaside destinations and new best practices will appear. The presented websites change regularly and the research reported here is a snapshot at one point in time.

This study was cross-sectional, but it could be argued that the results of collaborative working are only revealed over time, therefore a longitudinal study will be better able to analyse the dynamics of collaboration between key stakeholders.

\section{References}

Aaker, D. A. (1991). Managing Brand Equity: Capitalizing on the value of a Brand Name. New York: The Free Press.

Anholt, S. (2006). Anholt City Brand Index- "How the World Views Its Cities" (2nd ed.). Bellevue, WA: Global Market Insight.

Anholt, S. (2010). Places-Identity, Image and Reputation. New York: Palgrave Macmillan.

Ansell, Ch., \& Gash, G. (2012). Stewards, mediators, and catalysts: Toward a model of collaborative leadership. The Innovation Journal: The Public Sector Innovation Journal, 17(1), 1-21.

Ashworth, G., \& Kavaratzis, M. (2007). Beyond the logo: Brand management for cities. Brand Management, 16(8), 520-531. http://dx.doi.org/10.1057/palgrave.bm.2550133

Blain, C., Levy, S. E., \& Ritchie, J. R. B. (2005). Destination Branding: Insights and Practices from Destination Management Organizations. Journal of Travel Research, 43, 328-338. http://dx.doi.org/10.1177/0047287505274646

Blumrodt, J., \& Palmer, A. (2012). Branding tourism sea side destinations through websites. Discussion Paper Academy of Management Meeting, August, 3-7.

Blumrodt, J. (2011). L'internet comme outil markéting communication distinctif pour vendre la côte française! In Mansfield, C., \& Seligman, S. (Eds.), Narrative and the Built Heritage-Papers in Tourism Research (pp. 86-115). Saarbrücken: VDM.

Buhalis, D. (2001). The Tourism Phenomenon: the New Tourist and Consumer. In Wahab, S., \& Cooper, C. (Eds.), Tourism in the Age of Globalization. New York: Routledge.

Burford, S. (2011). Complexity and the Practice of Web Information Architecture. Journal of the American Society for Information Science and Technology, 62(10), 2024-2037. http://dx.doi.org/10.1002/asi.21582

Caldwell, N., \& Freire, J. R. (2004). The differences between branding a country, a region and a city: Applying the Brand Box Model. Journal of Brand Management, 12(1), 50-61. http://dx.doi.org/10.1057/palgrave.bm.2540201

Crosby, B. C., \& Bryson, J. (2010). Integrative Leadership and the Creation and Maintenance of Cross-Sector Collaborations. The Leadership Quarterly, 21(2), 211-30. http://dx.doi.org/10.1016/j.leaqua.2010.01.003

De Chernatony, L., (2001). A model for strategically building brands. Brand Management, 9(1), 32-44. http://dx.doi.org/10.1057/palgrave.bm.2540050

De Chernatony, L., \& Segal-Horn, S. (2001). Building on services' characteristics to develop successful services brands. Journal of Marketing Management, 17, 645-669. http://dx.doi.org/10.1057/palgrave.bm.2540050 
Echtner, Ch. M., \& Ritchie, J. R. B. (1991). The Meaning and Measurement of Destination Image. Journal of Tourism Studies, 2(2), 2-12. http://dx.doi.org/10.1362/026725701323366773

Florek, M., Insch, A., \& Gnoth, J. (2006). City council websites as a means of place brand identity communication. Place Branding, 2(4), 276-296. http://dx.doi.org/10.1057/palgrave.pb.6000036

Garrod, B., \& Fyall, A. (2000). Managing heritage tourism. Annals of Tourism Research, 27(3), 682-708. http://dx.doi.org/10.1016/S0160-7383(99)00094-8

Goeldner, C. R., \& Ritchie, Jr. B. (2012). Tourism: Principles, Practices, Philosophies (12th ed.). Hoboken, New Jersey: John Wiley \& Sons.

Gold, J. R., \& Ward, S. V. (1994). Place Promotion: The Use of Publicity and Marketing to Sell Towns and Regions. Chichester: John Wiley \& Sons.

Grant, I., \& McLeod Ch. (2007). Advertising agency planning-conceptualising network relationships. Journal of Marketing Management, 23(5-6), 425-442. http://dx.doi.org/10.1362/026725707X212757

Grimes, J. (2004). Creative Inspiration. The Communications Challenge: A Practical Guide to Account Planning. London: Account Planning Group.

Han, J. H., \& Mills, J. E. (2006). Zero Acquaintance Benchmarking at Travel Destination Websites: What is the First Impression that National Tourism Organizations Try to Make? International Journal of Tourism Research, 8, 405-430. http://dx.doi.org/10.1002/jtr.581

Hanna, S., \& Rowley, J. (2008). An analysis of terminology use in place branding. Place Branding and Public Diplomacy, 4(1), 61-75. http://dx.doi.org/10.1057/palgrave.pb.6000084

Hildreth, J. (2010). The Saffron European City Brand Barometer. Retrieved from http://saffron-consultants. com/news-views/publications

Inskeep, E. (1991). Tourism Planning: An integrated and sustainable development approach. London: Routlege.

Kavaratzis, M. (2009). Cities and their brands: lessons from corporate branding. Place Branding and Public Diplomac, 5(1), 26-37. http://dx.doi.org/10.1057/pb.2008.3

Kearns, G., \& Philo, C. (1993). Selling Places: The City as Cultural Capital, Past and Present. Oxford: Pergamon Press.

Keller, K. L. (1993). Conceptualization, Measuring, and Managing Customer-Based Brand Equity. Journal of Marketing, 57, 1-22. http://dx.doi.org/10.2307/1252054

Keller, K. L. (2008). Strategic Brand Management: Building, Measuring and Managing Brand Equity (3rd ed.). Englewood Cliffs, NJ: Prentice-Hall.

Kim, I., Han, D., \& Schultz, D. E. (2004). Understanding the diffusion of integrated marketing Communications. Journal of Advertising Research, 44(1), 31-45. http://dx.doi.org/10.1017/S0021849904040024

Kotler, P., Haider, D. H., \& Rein, I. R. (1993) Marketing Places: Attracting Investment, Industry and Tourism to Cities, States and Nations. New York: Free Press/Macmillan.

Lucarelli, A., \& Berg, P. O. (2011). City branding: a state-of-the-art review of the research domain. Journal of Place Management and Development, 4(1), 9-27. http://dx.doi.org/10.1108/17538331111117133

Matson, E. W. (1994). Can cities market themselves like Coke and Pepsi do? International Journal of Public Sector Management, 7(2), 35-41. http://dx.doi.org/10.1108/09513559410055215

McLemore, Ch., \& Mitchell, N. (2001). An Internet conversion study of www.arkansas.com-A state tourism website. Journal of Vacation Marketing, 7(3), 268-274. http://dx.doi.org/10.1177/135676670100700307

Mobley, A. M. (2008). Sharing the dream: The opening ceremonies of Beijing. Journal of Sport and Social Issues, 32(4), 327-332. http://dx.doi.org/10.1177/0193723508326935

Morgan, N., Pritchard, A., \& Piggot, R. (2002). New-Zealand, 100\% pure. The creation of a powerful niche destination brand. Journal of Brand Management, 9(4), 335-354. http://dx.doi.org/10.1057/palgrave.bm.2540082

Parkerson, B., \& Saunders, J. (2004). City branding: can goods and services branding models be used to brand cities? Place Branding and Public Diplomacy, 1(3), 242-264.

Rayman-Bacchus, L., \& Molina, A. (2001). Internet-based tourism services: business issues and trends. Futures, 33, 589-605. http://dx.doi.org/10.1016/S0016-3287(01)00003-9 
Savaneviciene, A., \& Stankeviciute, Z. (2011). The Interaction between Top Management and Line Managers Implementing Strategic Directions into Praxis. Inzinerine Ekonomika-Engineering Economics, 22(4), $412-422$.

Thill, J. V., \& Bovee C. L. (2010). Excellence in business communication (9th ed.). Portland: Mcgraw-Hill College.

Ward, S. V. (1998). Selling Places: The Marketing and Promotion of Towns and Cities 1850-2000. London: E\&FN Spon.

Woodside, A. G., Vicente, R. M., \& Duque, M. (2011). Tourism's destination dominance and marketing website usefulness. International Journal of Contemporary Hospitality Management, 23(4), 552-564. http://dx.doi.org/10.1108/09596111111130038

World Tourism Organization. (2012). UNTWO World Tourism Barometer. Committed to Tourism, Travel and the Millennium Development Goals, 10, 1-33.

Zenker, S. (2009). Who's your target? The creative class as a target group for place branding. Journal of Place Management and Development, 2(1), 23-32. http://dx.doi.org/10.1108/17538330910942771

Zenker, S. (2011). How to catch a city? The concept and measurement of place brands. Journal of Place Management and Development, 4(1), 40-52. http://dx.doi.org/10.1108/17538331111117151

\section{Copyrights}

Copyright for this article is retained by the author(s), with first publication rights granted to the journal.

This is an open-access article distributed under the terms and conditions of the Creative Commons Attribution license (http://creativecommons.org/licenses/by/3.0/). 